\title{
Optimum Maturity and Quality Parameters in Grapes: A Review'
}

\author{
C.S. DU PLESSIS
}

Viticultural and Oenological Research Institute, Private Bag X5026,

7600 Stellenbosch, Republic of South Africa.

Submitted for publication: February 1984

Accepted for publication: March 1984

\begin{abstract}
The quality of wine is without doubt largely dependent on the composition of the berries (Biol, 1977). In studies on grape quality, aspects of physiological, technological and industrial maturities have been covered by Kourakou (1974, 1977) and Marteau \& Schaeffer (1978). These maturities refer to stages in the grape which are respectively, those where sugar production in the berry has generally ceased, where the grape has reached optimum quality and finally where grapes would give the most economical return. Burger (1977) pointed out the necessity for specifying parameters which could be used to classify grape quality. This also includes

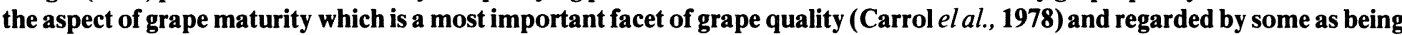
even more critical in this respect than viticultural practices (Slesinger, 1975).
\end{abstract}

Polysaccharides: The soluble polysaccharides of must have been indicated by Dubourdieu, Hadjinicolaou \& RibéreauGayon (1981) to give a possible indication of maturity of grapes in Bordeaux. With regard to Sémilion, the best results are achieved with respect to the extraction and clarification of the juice during the wine making process when the grapes are the most mature and the soluble pectins in the juice at a minimum. These researchers showed that especially the pectins, increased in both Sauvignon blanc and Sémilion to a maximum before decreasing to a minimum during maturation.

Potassium and pH: The importance of cations and $\mathrm{pH}$ with respect to technological maturity has been reported (Kourakou, 1974). The latter authority used potential alcohol (sugar) with $\mathrm{pH}$ to determine technological maturity. Maturity of grapes was related to $\mathrm{pH}$ alone by La Rosa (1955) who recommended specific $\mathrm{pH}$ values for harvesting different cultivars. However, Amerine (1956), although agreeing as to the importance of $\mathrm{pH}$ was of the opinion that it can only be a partial answer in defining a standard for harvesting.

It has been suggested that the quality of Rioja wine is influenced by the potassium content of the grape (Jaime Y Baro, 1973). Supplementation of potassium in potassium deficient grapes improved organoleptic quality of the wine. Hale (1977) could not determine a potassium/malate relationship during the acid accumulating stage of the berry but did find a relationship during ripening. However, no potassium/tartrate relationship was found. Somers (1977) discussed a connection between potassium levels in the harvest and relative quality of Australian red wines. $\mathrm{He}$ noted a significant positive correlation between degree of ionisation of the anthocyanins and quality rating of wines (Somers \& Evans, 1974). The degree of ionisation of the anthocyanins was primarily affected by $\mathrm{pH}$ which was in turn significantly and positively correlated to potassium levels. A point of interest was the indication that Australian and French red wines differed appreciably in their potasium concentration and $\mathrm{pH}$ values and subsequently in the degree of ionisation of the anthocyanins.

Phenolics: A study by Wucherpfennig et al. (1972) showed that leuco-anthocyanins in the grapes of Riesling, Silvaner and Sémilion grown at the sea of Marmara, decreased with ripening to a minimum prior to increasing again (Fig. 1). The leuco-anthocyanin concentration was related to polyphenol concentration and the pleasant taste ("Wohlgesch-

'Presented at the XVIII th congress of the O I V. Cape Town 1983. mack") of white wines was noted as not being dependent on only sugar/acid relationships but also strongly negatively influenced by the increasing concentration of polyphenols. An optimum stage of maturity of the grapes was shown at the lowest leuco-anthocyanin concentration which occurred at $16^{0}-17^{0}$ Brix $\left(60^{\circ}-70^{\circ} \mathrm{Oe}\right)$. Furthermore, it was determined in a survey of German wines that those of the northern areas (eg. Mosel) which are known to be light and elegant have low leuco-anthocyanin concentrations whereas those from the more southern and warmer areas (Baden) are fuller and showed higher leuco-anthocyanin concentrations. Work from the V O R I (Du Plessis, C.S., 1971, unpublished data) found the highest wine quality and lowest total polyphenols in the wine from Chenin blanc harvested at $16^{\circ} \mathrm{B}$ with partial de-acidification of the must but this could not be confirmed in subsequent results. However, Watanabe et al. (1976) found that white wines containing lesser amounts of polyphenols had the best taste and aroma. In an earlier study on white wines Watanabe et al. (1974) found no correlation between total polyphenols and sensory evaluation but found a good correlation between sensory evaluation and leucoanthocyanin concentration confirming the findings of Wucherfpennig et al.(1972). Sirota, Ivanyutina \& Pavlenko

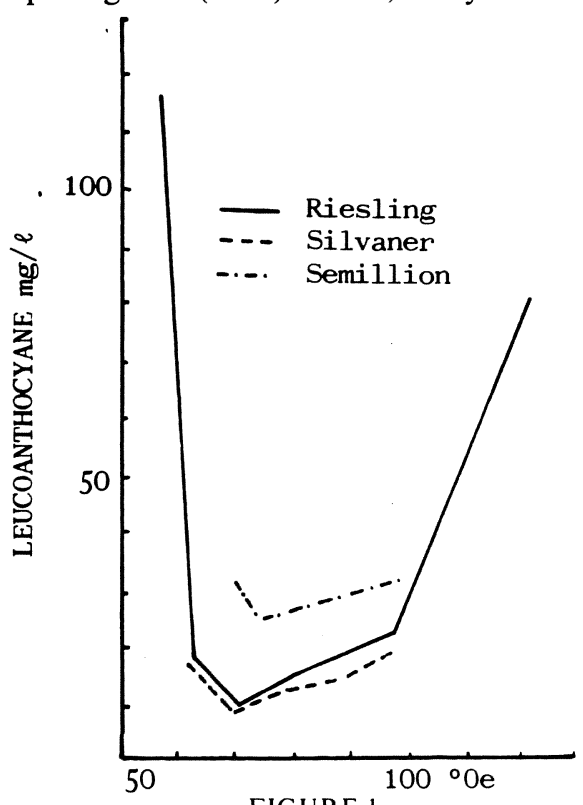

FIGURE 1

Leucoanthocyanin concentration $(\mathrm{mg} / \ell)$ of must from Riesling, Silvaner and Sémilion grapes in relation to maturity $\left({ }^{\circ}\right.$ Oechsle) (Wucherpfennig et. al., 1972). 
(1979) noted that the amount of phenolic compounds in white must was proportional to the degree of turbidity. With respect to the best colour of red wines Marteau \& Schaeffer (1978) reported from data of Ribéreau-Gayon (1972) that anthocyanins and tannins reach a maximum at maturity. This is approximately when the sugar concentrations attain the highest values. Lepadatu, Alexu \& Mujdaba (1972) indicated that maximum colour occurred in only $35 \%$ of the cases at maturity while in the balance this occurred up to 25 days later. It seems that climatic conditions can also influence this phenomenon. A study on Cabernet Sauvignon in French vineyards by Carbonneau et al. (1978) showed that wine quality was positively correlated with polyphenol content. Tromp (1977) similarly found good positive correlations of the total polyphenol concentrations of Cabernet Sauvignon wines, made from grapes of different maturities. However, only certain phenolic fractions in the grape skins correlated well with wine quality. It was indicated that the phenolics were modified during the wine making process to such an extent that the total polyphenols in the skins did not correlate with the final wine quality.

A most important aspect of the role of phenolics in wine quality was shown in a study with synthetic media (Du Plessis, 1970). A marked improvement in the bouquet of a fermented synthetic grape juice medium was brought about by the addition of an o-hydroxyphenol (e.g. $150 \mathrm{mg}$ protocatechuic acid per liter) to the medium prior to fermentation. The malodorous cabbagy aroma, which is typical of fermented synthetic media, was replaced by a clean bouquet with no sign of the malodorous characteristic. It was suggested that this role of polyphenols which did not appear to be that of a reducing agent, could also be effective in juice.

Turbidity and solids: The suspended material in must was indicated to be of importance in respect of wine quality and the must should contain 20-30 g per liter before fermentation (Sirota et al., 1979). In fact, with regard to red wines Siegrist \& Leglise (1981) suggested that the quality evaluation of grapes prior to harvest should also include the solid

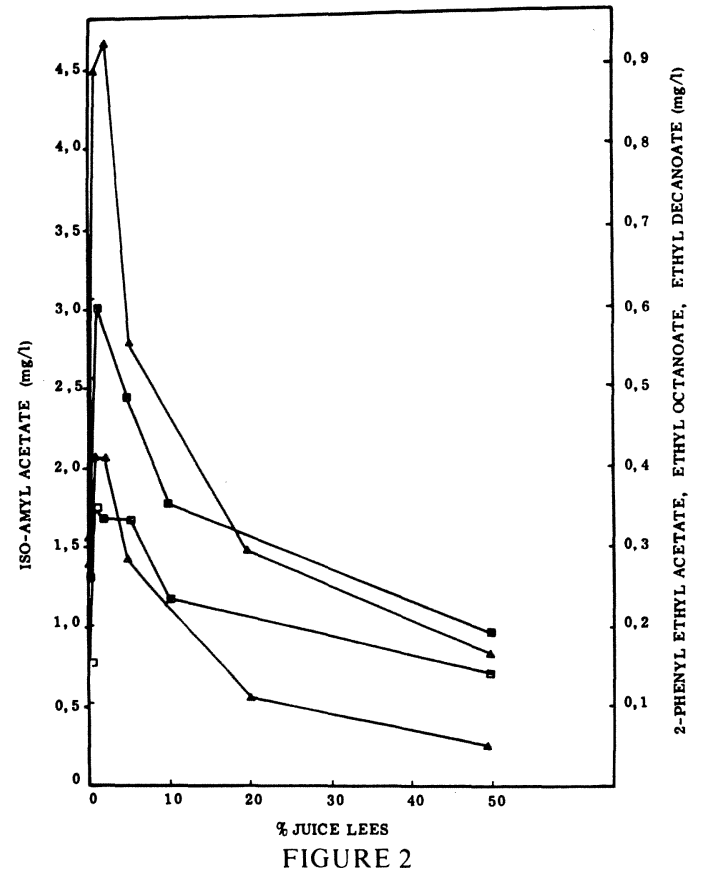

Effect of the addition of juice lees to sterile filtered juice on ester formation under a naerobic conditions $\mathbf{\Delta}=\mathrm{i}$-Amyl acetate. $\Delta=2$-Phenyl ethyl acetate. $\square=$ Ethyl octanoate. $\square=$ Ethyl decanoate (Houtman et. al., 1980). phase/liquid phase ratio. Du Plessis (1977) studied the influence of juice clarity on white wine quality and showed that turbidity per se or solids mass did not necessarily relate to wine quality. It was indicated that particle size could be of importance and where the largest particles were indicated to be the most detrimental to white wine quality. The turbidity in must was shown to influence the aroma volatiles of wines negatively (Ribéreau-Gayon, Lafon-Lafourcade \& Bertrand, 1975; Bertrand, Marly-Brugerolle \& Sarre 1978; Van Wyk, 1978). Houtman, Marais \& Du Plessis (1980) found that high concentrations of juice solid particles can have a negative effect and low concentrations a positive effect on formation of wine aroma components, e.g. esters (Fig. 2). Juice turbidity in terms of wine quality was noted as an incompletely defined factor but was without doubt most important.

Nitrogenous compounds: Drawert (1963) reported that in developing grapes, an average stage of maturity could be deduced from the attainment of a concentration "plateau" of summed amino acids. It was shown that proline correlated very closely with summed amino acid concentrations in ripening grapes (Du Plessis, 1977). Ough \& Alley (1970) suggested that proline may be a usable indicator of relative wine quality for "Thompson Seedless" grapes. In subsequent studies Ough \& Stashak (1974) noted a generally positive relationship between sugar and proline accumulation in grape berries. The relationship between proline concentration in grapes and subsequent wine quality has not yet been clearly shown. Modi \& Guerrini (1975) noted that Italian DOC wines generally show relatively constant but higher concentrations of proline than uncertified wines. Du Plessis (1975) found no clear relationship between proline concentration in Chenin blanc grapes and wine quality. (Fig. 3).

Ough (1969) found that under warm conditions the changes of ammonia concentration in grapes were relatively constant and could be useful to the Brix/acid ratio in predicting optimum maturity (Fig. 4).

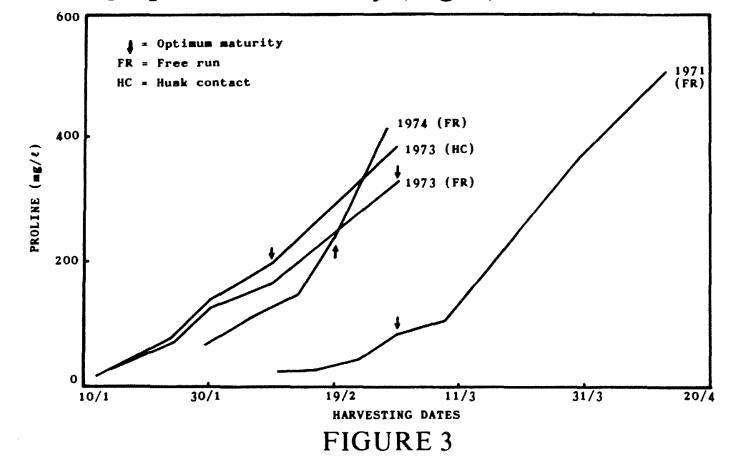

Proline concentration in ripening Steen grapes for years 1971, 1973 and 1974 (Du Plessis, 1975).

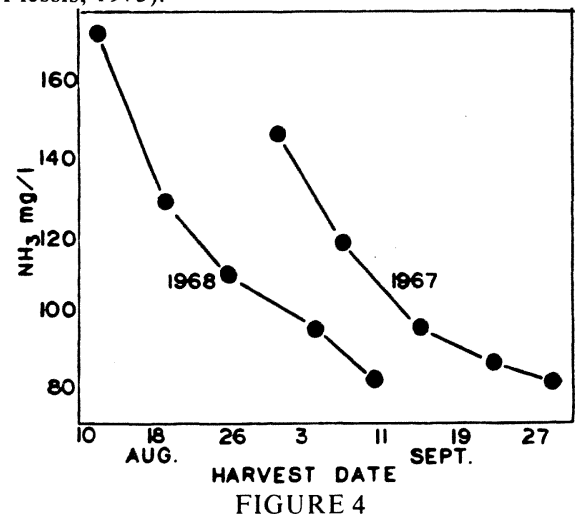

Change in the ammonia content of Thompson Seedless grapes from Kearney Field Station over the normal harvest period (Ough, 1969). 
Botrytis cinerea: It has long been known that Botrytis cinerea infection of white grapes can drastically affect the wine type that can be made from such grapes. Junge (1976) reported on the use of the "extract residue", as determined by Rebelein's formula, as an objective support parameter in sensory evaluation data of i.a. wines made from Botrytis cinerea infected grapes. Dittrich (1975) made a detailed study of the effect of Botrytis cinerea on many chemical components of the grape but did not relate these to quality. It has been noted that Botrytis cinerea ("pourriture grise") has become a major problem in Europe and can seriously harm wine quality (Gärtel, Bolay \& Biol, 1977). The "vinegary" impression which is often found in wines from Botrytis cinerea infected grapes can be caused by ethyl acetate. However, Sponholz \& Dittrich (1979) point out that ethyl acetate formation in wines made from "vinegary" grapes is not necessarily high and can not be taken as sole criterion of attack on musts by acetic acid bacteria. Cassignard (1977) paid particular attention to the degree of infection by Botrytis cinerea and its effect on loss of typical cultivar flavour.

Physical aspects: Poulton (1970) investigated aspects of harvesting grapes for maximum profit which could be called industrial maturity. He determined at what stage of maturity (Balling/ total acidity) the quality was the highest and simultaneously measured berry mass at these various stages. From these data and payment formulae he could deduce at what stage it should be economically most advantageous to harvest. This approach is similar in many respects to that of Marteau \& Schaeffer (1978) who reported that the date of industrial maturity of the grape i.e. when the grape has physiologically attained maximum sugar content, can be determined from the product of sugar/ml juice multiplied by the mass of 100 berries. This maturity index relates to the very important economic aspects but not as much to actual wine quality.

It has been found that Chenin blanc grapes taken on the same day from different vineyards show clearly different relationships between berry volume and ${ }^{0}$ Balling for the different degrees ${ }^{0}$ Balling of the berries (Du Plessis, C.S. 1969, unpublished data) (Fig. 5).

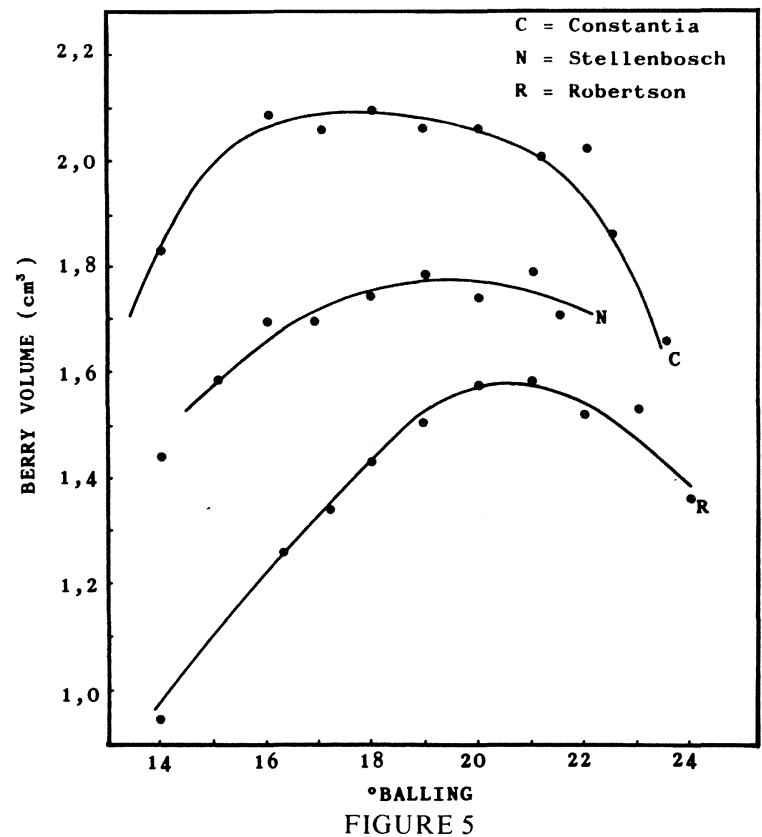

Berry volumes of one composite sample per vineyard of Chenin blanc grapes in Constantia, Stellenbosch, and Robertson in relation to their total soluble solids $\left({ }^{\circ} \mathrm{B}\right)$.
Aroma compounds: An important group of grape components which can be classified as quality parameters, are the terpenes and related components. Austerweil (1946) suggested that the aroma of muscat type grapes could be due to terpenes and especially linalool and its derivatives. Stevens et al. (1966) determined that linalool and geraniol definitely contribute to overall wine aroma. Wenzel \& De Vries (1968) added linalool to a neutral wine but found that a panel could not clearly associate linalool with the muscat character. However, Terrier, Boidron \& Ribéreau-Gayon (1972) noted that linalool and geraniol play an important role in muscat aroma. Bayonove \& Cordonnier (1971) found that some grapes with strong muscat flavour had low linalool concentration so that linalool concentration alone could not be used for analytical characterization of Muscat grapes. Webb, Kepner \& Maggiora (1966) noted similar results. An important finding of Ribéreau-Gayon, Boidron \& Terrier (1975) was that terpenes could react additively so that a mixture could be more aromatic than the most aromatic components in such a mixture. In similar context Mndzhoyan, Saakayan \& Saakayan (1971) reported that the aroma of a particular grape cultivar appears to be affected also by the quantitative relationship between the terpenes.

These aroma compounds in grapes have been shown to be mainly influenced by the stage of grape development. Hardy (1970) reported that the muscat aroma compounds increased in Muscat of Alexandria as long as the grapes remained on the vine but increases were most rapid during the final stages of ripening. Bayonove \& Cordonnier (1970) showed that a component indicated to be linalool, is initially absent in the grape but subsequently increases to a maximum with maturation before it again decreases (Fig. 6). Similar data were reported by Marteau \& Schaeffer (1978) with a decrease at industrial maturity or at slight over-maturation. Bayonove, Richard \& Cordonnier (1976) also note that trans-hotrienol, a major constituent of muscat aroma, also increases with ripening of the grapes.

It was found that the behaviour of specific terpenes differed with ripening; some increased, some decreased whilst others showed little change (Rapp et al. 1978). Similar and dissimilar patterns of these terpenes during ripening was determined in warmer conditions in South Africa by Augustyn, Rapp \& Engel (1980). However, Haushofer (1978) advises that harvesting be done when grape aromatic compounds are at a maximum which rarely coincides with the time of maximum sugar level. Terrier et al. (1972) report much the same tendency viz. that terpenes attain a maximum approximately 10-15 days before physiological maturity.

It appears that although some researchers are of the opinion that e.g. the quality of muscat grapes is a function of the linalool concentration in the must (Di Stefano, 1981) others are not as optimistic. However, it is accepted that terpenes are important quality factors in muscat type grapes. Terrier et al. (1972) give an index for terpenes at maturity by also taking the sugar and acidity of the grapes into consideration. Wagner et al. (1977) came to very much the same conclusion as the latter authors viz. that an indication of the degree of maturation of grapes deduced from the linalool/ geraniol ratio, could be complemented by sugar and organic acid concentration ratios. They furthermore propose that the concentration of these aroma constituents should be able to indicate the quality of the harvest more accurately than sugar concentration. Cordonnier \& Bayonove (1978) emphasized the importance of harvesting at the correct stage on quality; too early harvesting can give a pronounced unpleasant grassy character whereas too late harvesting results in a loss of aroma. However, Simpson (1979) noted that validity 


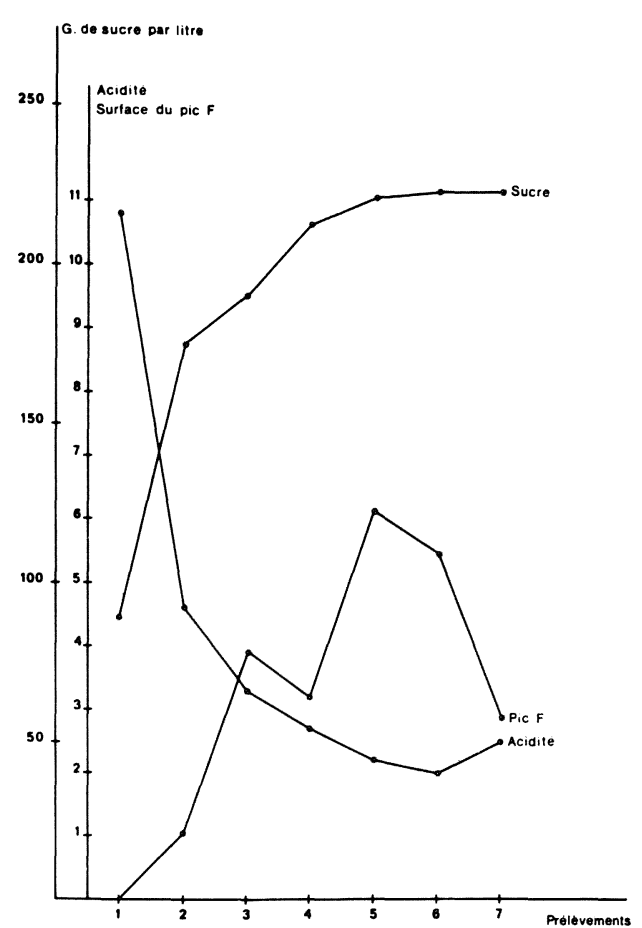

FIGURE 6

Evolution of linalol, the sugar and the acidity in the course of the maturation (Bayonove \& Cordonnier, 1970).

of the terpenes as grape maturity indicators must still be shown.

A second group of compounds which contribute to the aroma of grapes and wine and consequently to quality are those which are responsible for the typical grassy character in e.g. Sauvignon blanc and Cabernet Sauvignon wines. Cordonnier \& Bayonove (1978) and Pistre \& Boubals (1978) noted that this aroma characteristic decreased in the Cabernet Sauvignon grape with maturation and stage of harvesting would therefore also be most important with respect to quality in the wine.

Augustyn, Rapp \& Van Wyk (1982) recently studied the volatile aroma components in Sauvignon blanc grapes. For the first time methional, which has a potato-like aroma and trans-2, cis-6-nonadienal with a green cucumber-like aroma were found in Vitis. Evidence of the presence of several pyrazines was found which were believed to be key substances responsible for the typical aroma present in grapes and wines of Sauvignon blanc. Bayonove, Cordonnier \& Dubois (1975) found that the addition of 2-methoxy-3-iso-butyl pyrazine to neutral red wine, at a concentration as low as 5 micrograms per liter resulted in an aroma in the wine reminiscent of Cabernet Sauvignon. The pattern of formation of these aroma compounds in the ripening of grapes is an aspect of quality which must also be investigated similarly to the terpenes.

Initial studies were done on analysing for specific grape components which were correlated to aroma of the wine (Du Plessis, 1972). A fraction could be separated from juice which, when fermented with a synthetic medium, gave rise to a pronounced fermentation bouquet; the results were however, such that they could not be applied in practice at that stage. A follow-up study to determine wine quality factors and subsequently their origin/precursors in grapes did not give results which could be related either directly or indirectly to quality-related grape components (Du Plessis, 1975) (Fig. 7).
Total soluble solids, total acidity, $\mathrm{pH}$ and ratios: The foregoing studies were motivated by a lack of applicable parameters which would indicate grape quality. Maturity of grapes has been recognised as a most important quality parameter (Amerine \& Roessler, 1958) and the Balling/acid ratios as indicators of maturity determined more than forty years ago (Amerine \& Winkler, 1941). Three groupings were noted, viz. A for cultivars having ${ }^{0}$ Balling/ acid ratios of below 28,6, 31,4 and 34,3 at $20^{\circ}, 22^{\circ}$ and $24^{\circ}$ Balling; B for cultivars exceeding these ratios at the three ${ }^{0}$ Balling and $\mathrm{C}$ for cultivars which at $20^{\circ}$ or $22^{\circ}$ Balling have a ratio of below those given but which exceed the ratio at a higher ${ }^{0}$ Balling. Depending on the particular group into which a cultivar falls and from which area it comes, it would be suitable for either a table or a dessert wine. These authors noted that the Balling/acid ratio was very helpful for a preliminary grouping of wine grape cultivars. Tudosie, Moleavin \& Chirosca (1972) noted that a specific cultivar, which accounts for 4-6\% of the total vineyards of Rumania, is at full maturity when the grape contains on average $217 \mathrm{~g} / \mathrm{l}$ sugar and 3,5-5,9 $\mathrm{g} / 1$ total acidity. Fazinic, et al. (1976) related sugar and acid concentrations of the must to grape quality. Flora \& Lane (1976) found that juice soluble solids, total acidity and their ratio were closely related to ripeness in Muscadine grapes. Freeman, Turkington \& Kaye (1976) suggested that sugar/acid balance of the grapes in their study was more important, with respect to quality than was the geographical source of the grapes. Although the ${ }^{0}$ Balling/acid ratio has generally been studied in the warmer wine areas as indicator of quality it was also applied in Switzerland when optimum maturity had to be determined more precisely than with ${ }^{0} \mathrm{Oe}$ alone (Reutlinger, 1972). This is important since it has been found that optimum quality in a specific Chenin blanc vineyard in South Africa was attained at total soluble solid values which varied between $20^{\circ}-24^{0}$ Balling for different years (Du Plessis, 1977). Berg \& Ough (1977) reported ${ }^{0}$ Balling requirements for Chenin blanc grapes and noted that these values ranged from $19^{0}-23^{\circ} \mathrm{B}$ for two climatic regions which in effect come close to the values reported earlier for optimum maturity in South Africa (Du Plessis, 1977). This indicated the inaccuracy of total soluble solids per se as a grape maturity parameter. In fact, it has been very succinctly stated that ${ }^{0}$ Balling "is practically useless as a measure of the quality that the grape is capable of obtaining" and that "the ${ }^{0}$ Balling/acid ratio should be used to achieve the optimum quality of the grapes to determine the time of picking" (Berg, 1958). Coombe, Dundon \& Short (1980) stated that the "balance between sweetness and acidity is a basic precept in man's judgement of the quality of many items of diet." In grapes this would relate to total soluble solids, of which by far the largest part is sugar, and total titratable acidity or $\mathrm{pH}$. The ${ }^{0} \mathrm{Brix} /$ acid ratio was studied by Ough \& Singleton (1968) as a means to predict wine quality. Indications, under their conditions of study, were that in cooler regions quality of wine was reasonably independent of maturity whereas in warmer areas an optimum level of maturity appeared to exist and could be related to ${ }^{0} \mathrm{Brix} /$ acid ratios of the fruit (Ough \& Alley, 1979). In fact, they found reasonably conclusively that a ${ }^{0} \mathrm{Brix} /$ percent acid ratio of 30-32 is near optimum wine quality for Thompson Seedless grapes (Fig. 8). Coombe et al. (1980) also studied indices of sugar and acidity as ripeness criteria for wine grapes. Using survey data from prominent South Australian winemakers they indicated that ${ }^{0} \mathrm{Brix} \times \mathrm{pH}^{2}$ gave acceptable criteria for defining ripeness in grapes. Sinton et al. (1978) studying grape juice indicators for prediction of potential quality found that ${ }^{0} \mathrm{Brix} \times \mathrm{pH}$ was the most practical indicator of 
aroma intensity $(r=+0,800)$ in Zinfandel wines. However, no significant correlation between ${ }^{0} \mathrm{Brix} \times \mathrm{pH}$ in the grapes and overall wine sensory scores could be found. Fanizza (1982) applied factor analysis to determine a suitable wine grape maturity index in hot areas. He found that firstly $\mathrm{pH}$ and secondly ${ }^{\circ} \mathrm{B}$ are most important variables. Recent work in South Africa showed that ${ }^{\circ}$ Balling/total acidity ratio and ${ }^{0}$ Balling $\mathrm{x}$ pH data on ripening grapes were very highly significantly correlated (Du Plessis \& Van Rooyen, 1982). These latter authors harvesting periodically from specific vineyards, found that a specific ${ }^{0}$ Balling/total acid ratio in the grapes could indicate optimum maturity significantly in the case of two white (Fig. 9) and two red cultivars. It was determined that the relationship between ${ }^{0}$ Balling/total acid ratio and wine quality was curvilinear and indicated a rapid attainment of optimum quality followed by a rapid decrease. Different cultivars had different ratio values at their optimum maturities under the specific conditions.

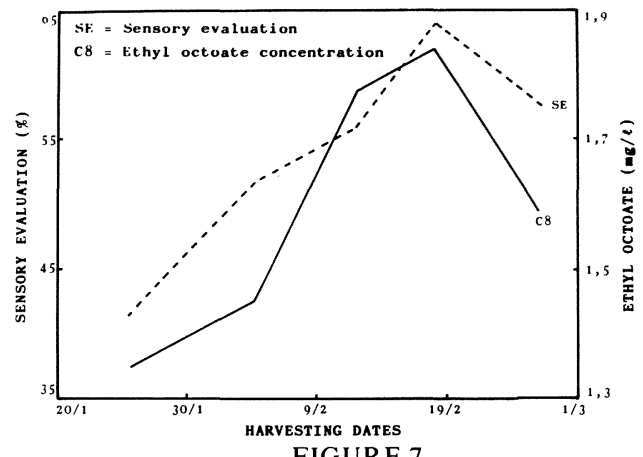

FIGURE 7

Sensory evaluations and ethyl octoate concentrations of wines made from periodically harvested Steen grapes (1974) (Du Plessis, 1975).

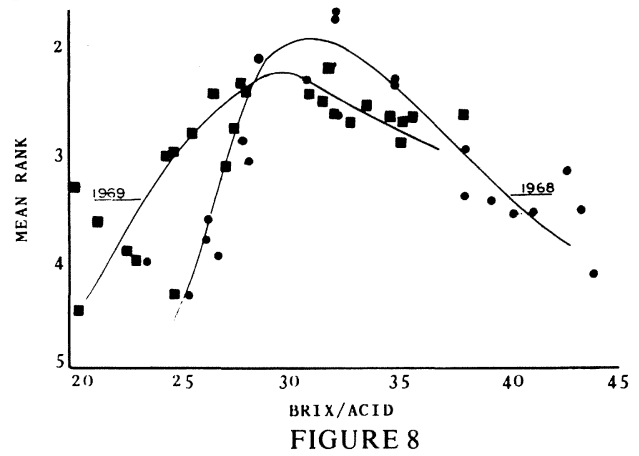

Comparison of quality-ranking data of wine to the Brix/acid ratio of the fruit for a two-year period (Ough \& Alley, 1970).

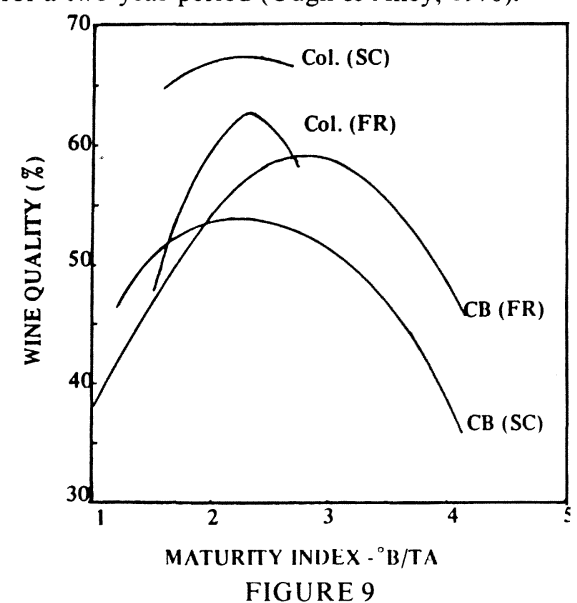

Fitted curves relating wine quality and grape maturity inde $\mathrm{x}^{\circ} \mathrm{B} / \mathrm{TA}$ for Chenin blanc (CB) and Colombar (Col.) data for free run (FR) and skin contact (SC) treatments for six seasons (Du Plessis \& Van Rooyen, 1982).
It has been shown in a detailed study on grape maturity parameters that seasons can occur where no clear maximum of wine quality at stipulated ${ }^{0} \mathrm{Balling} /$ total acid ratios occur (Du Plessis \& Van Rooyen, 1982) (Fig. 10). It is considered that the application of the latter parameters can be of more use in the warmer than the colder viticultural areas (Ough \& Singleton, 1968). However, even under warmer conditions the sugar and acidity or $\mathrm{pH}$ maturity indices are not sufficiently consistent. It has been shown that especially in warm areas requiring irrigation the ${ }^{0} \mathrm{Balling} /$ total acid ratio in grapes can sometimes be relatively ineffective in defining optimum maturity in grapes (Du Plessis \& Lüttich, 1982). The influence of irrigation in causing marked fluctuations in the normally relatively steady increases in $\mathrm{pH}$ in the grape with ripening can lead to inaccuracies in determining optimum maturity in grapes (Du Plessis \& Rossouw, 1978). Fig. 11 shows the fluctuations which can occur and could lead to erroneous ratios.

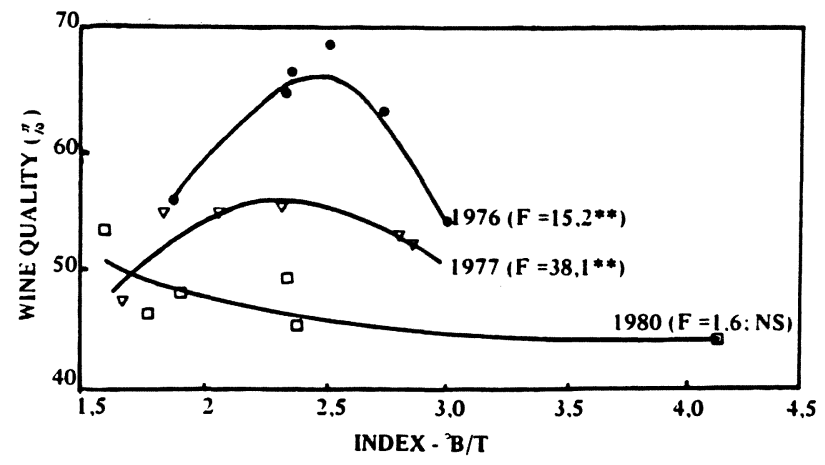

FIGURE 10

Fitted curves and observed data for Chenin blanc for three years relating wine quality and grape maturity $\left({ }^{\circ} \mathrm{B} / \mathrm{TA}\right)$ (Du Plessis \& Van Rooyen, 1982).

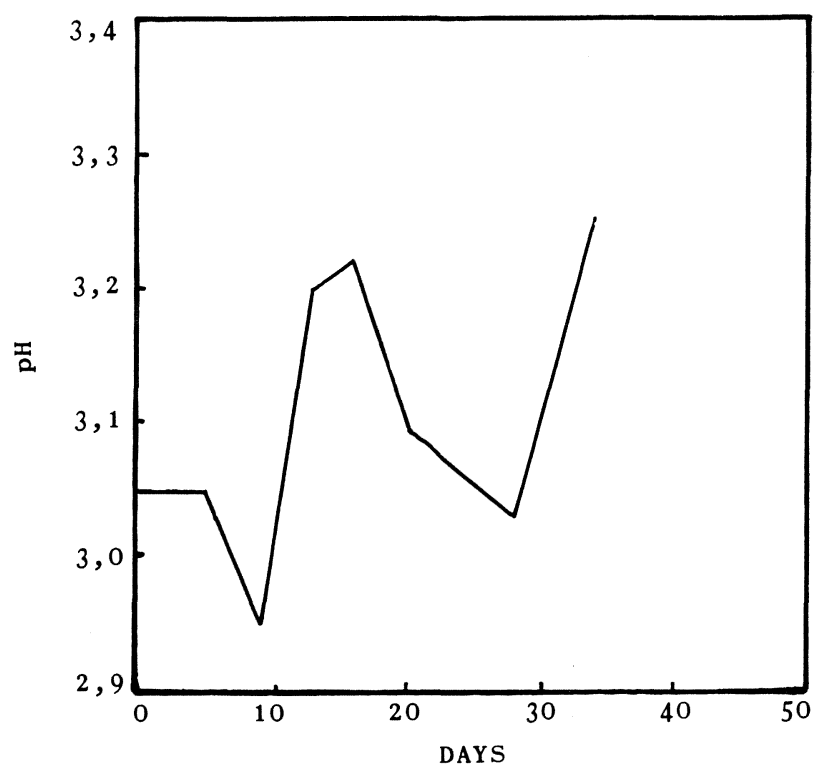

FIGURE 11

Marked variations in $\mathrm{pH}$ of the juice of Colombar grapes that were irrigated. The grapes are from the same vineyard but harvested at different times.

The very real need to predict accurately the time of harvest to make the best wine possible, has led to the development of a grape quality assessment scheme by Cootes, Wall \& 
Nettlebeck (1981). This most interesting scheme, uses the following categories:

- aroma and taste of the juice

- altitude of the vineyard

- degrees Baumé

- titratable acidity

- $\mathrm{pH}$

- physical condition of the grape sample and

- sulphur dioxide concentration of the juice.

Grapes are assessed and the total bonus percentage gained determined which the authors relate to grape quality and for which the producer is imbursed. Cootes et al. (1981) reported that the aroma of Riesling grapes from three vineyards correlated with wine quality score $(r=0,96)$. It was noted that grape juice flavour was not correlated with either ${ }^{0}$ Baume or $\mathrm{pH}$. On the other hand titratable acidity of the grapes could be significantly correlated with wine quality for the one year of the study. An interesting aspect of the assessment scheme was not to use the maturity index " $R$ " $\left({ }^{0} \mathrm{Brix} \mathrm{x} \mathrm{pH}^{2}\right)$ of grapes of Coombe et al. (1980) but to replace it with appropriate range of ${ }^{0} \mathrm{Be}$ and $\mathrm{pH}$ in the grapes of each cultivar. The main hypothesis for this approach was that grape ripeness covers a wide range of chemical analysis (Cootes et al., 1981). If has been found that under South African conditions wine quality of ripening Chenin blanc can decrease by $10 \%$ within a week so that optimum maturity is attained and passed relatively rapidly (Du Plessis $\&$ Rossouw, 1978). It may be that for certain cultivars where grape flavour is important, ripeness can occur over a wider range than for others and ${ }^{0} \mathrm{Be}$ and titratable acidity specifications may have to be weighted differently. The cultivar Chenin blanc e.g. is specified by Cootes et al. (1981) as having to be in the range $11,5-13,5^{\circ} \mathrm{Be}$ (ca $20,80-24,4^{\circ} \mathrm{Brix}$ ) and $7-10 \mathrm{~g} / 1$ titratable acid to gain the maximum bonus for these categories. It is known that Chenin blanc grapes of $11,5^{\circ} \mathrm{Be}$ (ca $20,8^{\circ} \mathrm{Brix}$ ) and $10 \mathrm{~g} / \mathrm{l}$ titratable acid will not give the best quality under South African conditions (Du Plessis \& Rossouw, 1978). The grape quality assessment of Cootes et al. (1981) is one of the most promising systems reported but, since it has only been applied for a short while, initial problems could occur which should be ironed out by further research.

\section{SUMMARY AND CONCLUSIONS}

The knowledge of quality parameters in grapes is of cardinal importance since wine quality is directly related to the quality of the vintage. In this review it was the aim to refer generally to components in grapes which can influence the quality, and also to consider grape quality in terms of maturity. There are other factors which can also have a bearing on quality such as cultivar, climate, soil, viticultural practices and wine making methods. It was shown that grape maturity can have a more marked effect on quality than several of the latter factors. This is most important, for should these factors be studied and the grapes not harvested at optimum maturity, then maturity effect as a quality factor could override that of the studied factor and give results which would be meaningless. In view of the fact that many researchers have used grape sugar or total soluble solids as a quality parameter and since its inaccuracy in this respect is known, it is highly probable that many results were obtained which did not reflect the effect of a studied paramater.

In addition to the terpenes there are also those components in grapes which give rise to the typical aroma characteristics of cultivars like Cabernet Sauvignon and Sauvignon blanc. The pyrazine group appears to be of marked importance here. Studies of this aroma parameter with respect to viticultural and oenological factors which affect its formation will, like the terpenes, give the information which will undoubtedly contribute to defining the conditions which effect consistently good wine aroma.

Relevant studies in grape quality parameters and grape maturity have covered very many components and conditions. In many of these studies strong claims are made on the correlation of the specifically researched grape component or component group with ultimate wine quality. A shortcoming of many of these studies was that the relationship of so few components, in many cases only one, was studied in relation to quality. It is doubtful whether grape quality can be consistently related to only one component or even a component group such as amino acids. Future work should seriously consider analysing as many components as possible, such as those noted in this paper. In this respect the computer is as necessary an instrument as is the gas chromatograph today. It has been possible to forecast by means of heat units, the optimum maturing date of "Concord" grapes (at least 16\% total soluble solids) correctly to within 4 days in 11 out of 13 years. Prediction of optimum maturity and possibly also quality by the use of computer programs is an exciting possibility.

In the warmer wine producing areas total soluble solids, acidity and $\mathrm{pH}$ ratios have been used for some time with a relatively good deal of success in determining optimum maturity in grapes. It was possible to predict optimum quality dates from simple extrapolation of relatively early season data. However, several workers have noted that sugar/acid ratios should be considered together with other factors such as polyphenols, ammonia and must solids to determine optimum grape maturity. It is considered that the use of statistical programs with these data in combination with that noted previously appears a most promising approach to defining and determining optimum quality parameters and maturity in grapes.

\section{LITERATURE CITED}

AMERINE, M.A., 1956. The maturation of wine grapes. Wines \& Vines. Oct. 27-30, 32, 34-36, Nov. 53-55.

AMERINE, M.A., \& ROESSLER, E.B., 1958. Field testing grape maturity. Hilgardia, 28, 93-114.

AMERINE, M.A., \& WINKLER, A.J., 1941. Maturity studies with California grapes I. The Balling-acid ratio of wine grapes. Proc. Amer. Soc. Hort. Sci. 38, 379-387.

AUGUSTYN, O.P.H., RAPP, A., \& ENGEL, L., 1980. The effect of maturity, region and temperature on the flavour profile of different cultivars and wines: (Afrik). Proc., Symposium of the South African Society for Enology and Viticulture. Cape Town. South Africa Oct. 30-31.

AUGUSTYN, O.P.H., RAPP, A., \& VAN WYK., C.J., 1982. Some volatile aroma components of Vitis vinifera L. cv. Sauvignon blanc. S. Afr. J. Enol. Vitic. 3, 53-60.

AUSTERWEIL, G., 1946. Quelques observations sur les parfums des vins. Ind. Parfum. 1, 195-199.

BAYONOVE, C., \& CORDONNIER, R., 1970. Recherches su làrome du muscat I. - Évolution des constituants volatils au cours de la maturation du "Muscat d'Alexandrie". Ann. Technol. Agric. 19, 79-93.

BAYONOVE, C., \& CONDONNIER, R., 1971. Linalol - an important but not specific consitituent of the aroma of Muscat grapes. Comptes rendus Hebdomadaires dus Seances de l'Academie d'Agriculture de France. 57, 1374-1377. (In FSTA, 4, 8T461, 210, 1972).

BAYONOVE, C., CORDONNIER, R., \& DUBOIS, P., 1975. Etude d'une fraction caracteristique de l'arome du raisin de la varieté Cabernet Sauvignon; mise én evidence de la 2-methoxy-3-isobutylpyrazine. C. R. Acad. Sc. Paris 281, 75-78.

BERG, H.W., 1958. Better grapes for wine (a symposium). Nature of the problem. Am. J. Enol. 9, 203-204. 
BERG, H.W., \& OUGH, C.S., 1977. The relation of ${ }^{0}$ Balling to wine quality. Am. J. Enol. Viticult. 28, 235-238.

BERTRAND, A., MARLY-BRUGEROLLE, C., \& SARRE, C. 1978. Influence du bourbage des mouts et du sulfitage sur les teneurs en substances volatiles des vins et des eaux-de-vie.1 Etude des vins. Conn. Vigne Vin. 12, 35-48.

BIOL, H., 1977. Less effets de la pourriture grise de raisins dans le cas de l'élaboration des vins rouges. Vignes Vins 264, 25-27.

BURGER, J.D., 1977. Paiement des produits de la vigne salon des sytemes tenant compte de la qualite de la vendange. Presented at the XV Congrès international de la vigne et du vin. O I V Nyon, Switzerland, July, 24-30.

CARBONNEAU, A., CASTERAN, P., LECLAIR, P., BOUSSION, C., COCHIN, R., GAZEAU, ODILE, \& LEGLISE, NICOLE, 1978. Attempt to define by whole plant biology, essential relations between natural bioclimate, vine physiology, and grape composition. Methodology and first results in training systems. Ann. Amelior. Plant. 28, 195-221, 1978. (In Chem. Abstr. 90 (1) 4397, 426, 1979)

CARROLL, D.E., BALLINGER, W.E., MCCLURE, W.F., \& NESBITT, W.B., 1978. Wine quality versus ripeness of light-sorted Carlos muscadine grapes. Am. J. Enol. Vitic. 29, 169-171.

CASSINGNARD, R., 1977. Conséquence d'une attaque de Botrytis cinerea (Pers) sur la qualité des vins blancs et des eaux-de-vie de vin. Vignes Vins. 264, 28-31.

COOMBE, B.G., DUNDON, R.J., \& SHORT, A.W.S., 1980. Indices of sugar-acidity as ripeness criteria for winegrapes. J. Sci. Food Agric. 31, 495-502.

COOTES, R.L., WALL, P.J., \& NETTLEBECK, R.J., 1981. Grape quality assessment. Presented at seminar on "Grape Quality: Assessment from vineyard to juice preparation." Australian Society of Viticulture and Oenology Inc. Melbourne.

CORDONNIER, R., \& BAYONOVE, C., 1978. Les composantes variétales at préfermentaires de l'arome des vins. Extrait de Parfum Cosmetiques arômes. 24, 67-77.

DI STEFANO, R., 1981. Composti terpenici del moscato del Piemonte. Vini d'Italia XXIII, 29-43.

DITTRICH, H.H., 1975. Comparative examination of sweet musts and wines made from sound and Botrytis-infected grape berries. Presented at 4 International Enological Symposium p 374-390. Valencia. Spain. May 26-29.

DRAWERT, F., 1963. Biochemisch-physiologische Untersuchungen an Traubenbeeren. Vitis 4, 49.56.

DUBOURDIEU, D., HADJINICOLAOU, D. \& RIBÉREAU-GAYON, P., 1981. Les polysaccharides solubles du mout: Methode simple d'appreciation; evolution au cours de la maturation; incidence sur les operations prefermentaires. Conn. Vigne Vin. 15, 29.40.

DU PLESSIS, C.S, 1970. A study of wine bouquet precursors in grapes. Thesis. University of Stellenbosch. Stellenbosch.

DU PLESSIS, C.S. 1972. A new approach to wine quality with special regard to bouquet. Presented at Third International Oenological Symposium. p. 5-1 to 5-8. Sea Point. South Africa. March 6.10.

DU PLESSIS, C.S., 1975. Fermentation formed components in relation to wine quality. Presented at Fourth International Enological Symposium. p. 374-390 Valencia. Spain. May 26-29.

DU PLESSIS, C.S., 1977. The influence of juice clarifying techniques and juice clarity on wine quality. Wynboer. 554, 67-70.

DU PLESSIS, C.S., \& ROSSOUW, H.A.C., 1978. Degree of grape maturity as quality parameter (Afrik). Presented at short course in oenology. V.O.R.I. Private Bag X5026, Stellenbosch, 7600, South Africa.

DU PLESSIS, C.S. \& LÜTTICH, B., 1982. Maturity parameters and practical application (Afrik). Presented at short course in oenology, V.O.R.I., Private Bag X5026, Stellenbosch, 7600, South Africa.

DU PLESSIS, C.S., \& VAN ROOYEN, P.C., 1982. Grape maturity and wine quality. S. Afr, J. Enol. Viticult. 3, 41-45.

FANIZZA, G., 1982. Factor analysis for the choice of a criterion of wine grape (Vitis vinifera) maturity in warm regions. Vitis 21, 333-336.

FAZINIC, N., BRIZA, K. MILOSAVLJEVIC, M., LAZIC, S., \& CONDRIC, P., 1976. Physiologie de la croissance et de la maturation des baie. Causes des variations des constituants principaux. Influence des opérations en vert et des interventions chimiques. Bull. Off. int. Vin. 49, 565-574.

FLORA, L., \& LANE, R.P., 1979. Effect of ripeness and harvest date on several physical and compositional factors of Conart muscadine grapes. Am. J. Enol, Viticult. 30, 241-246.

FREEMAN, B.M. TUR KINGTON, C.R., \& KAYE, G.R., 1976. Quality assessment of Hunter Valley and Griffith experimental varietal wines. Austr. Wine Brew. Spirit Rev. March, 35-36.
GÄRTEL, W., BOLAY, A., \& BIOL H., 1977. Les problèmes posés par la pourriture grise sur la vigne comment les resoudre. Vignes Vins. 260,7, 9.18

HALE, C.R., 1977. Relation between potassium and the malate and tartrate contents of grape berries. Vitis 16, 9-19.

HARDY, P.J., 1970. Changes in volatiles of muscat grapes during ripening. Phytochemistry 9, 709-715.

HAUSHOFER, H., 1978. Élaboration et conservation des vins blancs aromatiques. Ann. Technol. Agric. 27, 221-230.

HOUTMAN, A.C., MARAIS, J., \& DU PLESSIS, C.S., 1980. Factors affecting the reproducibility of fermentation of grape juice and of the aroma composition of wines. I. Grape maturity, sugar, inoculum concentration, aeration, juice turbidity and ergosterol. Vitis 19, 37-54.

JAIME Y. BARO, A.L., 1973. Influence of different levels of potassium content on the quality of Rioja wines. Semana Vitivinicola, 28 (1385) 647-651 (Es.). (In FSTA 6, 9H1385, 55, 1974).

JUNGE, CHARLOTTE, 1976. Qualitäteinstufung von Wein mit Hilfe chemischer Kennzahlen. Wein und Rebe 58, 235-240.

KOURAKOU, S., 1974. Optimaler reifergrad der Trauben in bezug auf den gewünschten weityp (Fr). Paper presented, XIV Congress international de la vigne et du vin. O.I.V. Bolzano. Italy, Oct.

KOURAKOU, S., 1977. Degrè de maturité optimale du raisin selon le type de vin à élaborer. Bull. Off. int. Vin. 50, 617-640.

LA ROSA, W.V., 1955. Maturity of grapes as related to $\mathrm{pH}$ at harvest. $\mathrm{Am}$. J. Enol. 6. $42-46$

LEPADATU, V. ALEXU, A., \& MUJDABA, F., 1972. Les anthocyanes variation de leur teneur selon le cépage et l'écosystème. Bull. Off. int. Vin. 45. 650-666.

MARTEAU, G., \& SCHAEFFER, A., 1978. Maturité optimale des raisins de cuve selon les types de vins à élaborer. Bull. Off. int. Vin. 51, 281-299.

MNDZHOYAN, EL., SAAKAYAN, R.G., \& SAAKAYAN, A.S., 1971. Terpene compounds. Vinodelie $i$ Vinogradarstvo SSSR 31, 18-19 (Russ.) In FSTA 4, 9H 1382, 58, 1972).

MODI, G., \& GUERRINE, G., 1975. Determination of proline in wines of various origins. Boll. Chim. Unione Ital. Lab. Prov. 1, 269.275 (Ital.) (In Chem. Abstr. 84 (5) 57343, 353, 1976).

OUGH, C.S., 1969. Ammonia content of California grapes. Am. J. Enol. Vitic. 20, 213-220.

OUGH, C.S., \& ALLEY, C.J., 1970. Effect of "Thompson Seedless" grape maturity on wine composition and quality. Am. J. Enol. Vitic. 21. 78-84.

OUGH, C.S. \& SINGLETON, V.L., 1968. Wine quality prediction from juice Brix/acid ratio and associated compositional changes for "White Riesling" and "Cabernet Sauvignon". Am. J. Enol. Viticult. 19, 129-138.

OUGH, C.S., \& STASHAK, R.M., 1974. Further studies on proline concentration in grapes and wines. Am. J. Enol. Viticult. 25, 7.12.

PISTRE, R., \& BOUBALS, D., 1978. Transmission héréditaire du goút de "Cabernet Sauvignon" dans les croisements de cette variété avec des cepages du Sud de la France p. 435-443. Genetique et Amelioration de la. Vigne. 11. Symposium international sur l'amelioration de la Vigne. I.N.R.A. Paris

POULTON, J., 1970. Harvesting grapes for maximum profit. Wynboer 460, 22-26.

RAPP, A., HASTRICH, H., ENGEL, L., \& KNIPSER, W., 1978 Possibilities of characterizing wine quality and vine varieties by means of capillary chromatography. In "Flavour of foods and beverages," 25, p 391-417. Ed., G. Charalambous, G.E. Inglett. Acad. Press. New York.

REUTLINGER, H., 1972. Wine making with the object of producing fruity wines. p. 12-1 to 12-8. Presented at Third Internation Oenological Symposium Sea Point. South Africa. March 6-10.

RIBÉREAU-GAYON, P., 1972. Evolution des composés phenoliques du cours de la maturation du raisin. Conn. Vigne Vin. 6, 161-175.

RIBÉREAU-GAYON, P., BOIDRON, J.N., \& TERRIER, A., 1975. Aroma of Muscat grape varieties. J. Agric. Food Chem. 23, 1042-1047

RIBÉREAU-GAYON, P., LAFON-LAFOURCADE, SUZANNE, \& BETRAND, A., 1975. Le debourbage des mouts de vendange blanche. Conn. Vigne Vin. 9, 117-139.

SIEGRIST, J., \& LEGLISE, M., 1981. Effect of the "solid phase/liquid phase" ratio of the vintage on red wine composition C.R. Seances Acad. Agric. Fr. 67, 300-311 (Fr) (In Chem. Abstr. 95 (7) 113318, 514 , 1981).

SIMPSON, R.F., 1979. Some important aroma components of white wine. Food Technol., Aust. 31, 516-522. 
SINTON, T.H., OUGH, C.S. KISSLER, J.J., \& KASIMATIS, A.N.,

1978. Grape juice indicators for prediction of potential wine quality. I. Relationship between crop level, juice and wine composition, and wine sensory ratings and scores. Am. J. Enol. Viticult, 29, 267-271.

SIROTA, G.G., IVANYUTINA, A.I., \& PAVLENKO, N.M., 1979. Clarification cycle in white wine production. Sadovod. Vinograd. Vinodel.. Mold. 34, 32.35. (In Chem, Abstr. 92(1) 4638, 453, 1980).

SLESINGER, Z., 1975. Untersuchungen über den Einfluss der Erziehungsnorm auf die Traubenstruktuur bei deur Sorte Veltliner frührot. Mitt Rebe, Wein, Obstbau und Früchteverwertung 25, 271-278.

SOMERS. T.C., 1977. A connection between potassium levels in the harvest and relative quality in Australian red wines. Presented at International Symposium on the Quality of the Vintage. p 143-148. Cape Town. South Africa. Feb. 14-21.

SOMERS, T.C., \& EVANS, M.E., 1974. Wine quality: Correlations with colour density and anthocyanin equilibria in a group of young red wines. J. Sci. Food Agric. 25, 1369-1379.

SPONHOLZ, W.R., \& DITTRICH, H.H., 1979. Analytische Vergleiche von Mosten und Weinen aus gesunden und essigstichen Traubenbeeren. Wein - Wissenschaft 34, 279-292.

STEVENS, K.L., BOMBEN, J., LEE, A., \& MCFADDEN, W.H., 1966. Volatiles from grapes. Muscat of Alexandria. J. Agric. Food Chem. 14, 249-252.

TERRIER, A., BOIDRON, J.N., \& RIBÉREAU-GAYON, P., 1972. Teneurs en composés terpeniques des raisins de Vitis vinifera. C.R. Acad. Sci. Ser. D. 275, 941-944.

TROMP. A., 1977. The influence of phenolic composition and colour on red wine quality (Afrik). MSc Thesis. Stellenbosch University. Stellenbosch. South Africa.

TUDOSIE, A.D., MOLEAVIN, V., \& CHIROSCA, J., 1972. Busuioaca de Bohotin, a high quality grape variety of the Husi vineyards. Industria Alimentara 23, 324-325 (Ro). (In FSTA. 6, 6H865, 57, 1974).
VAN WYK. C.J., 1978. The influence of juice clarification on composition and quality of wines. Presented at 5th International Oenological Symposium p. 32-45. Auckland, New Zealand. Feb. 13-15.

WAGNER, R., DIRNINGER, N., FUCHS, V., \& BRONNER, A., 1977. Study of the intervatietal differences in the concentration of volatile constituents (linalool and geraniol) in the aroma of the grape. Interest of such analyses for the appreciation of the quality of the harvest. Presented at International Symposium on the Quality of the Vintage. p. 137-142. Cape Town. South Africa. Feb. 14-21.

WATANABE, M., KAGAMI, H., OGINO, S., MIMORI, T., \& KAZAMA, K., 1974. Polyphenols in wine. I. Correlation between the polyphenol components and the quality of white wine. Nippon Jozo Kyokai Zasshi. 69, 705-708 (Jap) (In Chem. Abstr. 82(10) 123272,405, 1975)

WATANABE, M., Otoguro, C., IINO, S., KAgAmi, H., \& KAZAMA, K., 1976. Studies on polyphenols in wine. Part 2. Sensory evalution and polyphenol content in wines presented at the 4-5th Yamanashi Prefectural Exhibition. Yamanashi-ken Sholkuhin Kogyo Shidosho Kenkyu Hokoku. 8, 75-80 (In Chem. Abstr. 88 (8), 103327, 410, 1978).

WEBB, A.D., KEPNER, R.E., \& MAGGIORA, LINDA, 1966. Gas chromatographic comparison of volatile aroma materials extract from eight different muscat-flavored varieties of Vitis vinifera. Am. J. Enol. Viticult. 17, 247-254.

WENZEL, K.W.O., \& DE VRIES, M.J., 1968. An investigation of muscat aroma. S. Afr. J. Agric. Sci. 11, 273-280.

WUCHERPFENNIG, K., HADI KHADEM, S., HENSEL, R., \& GÖRGEN, W., 1972. Uber dem Leucoanthocyangehalt vom Weissen Trauben im Verlauf der Reife, von Mosten bei der Verarbeitung und von Weissweinen. Weinberg und Keller. 19, 449-466. 